\title{
Role of CD44 in the Reaction of Vascular Smooth Muscle Cells to Arterial Wall Injury
}

\author{
Mukesh Jain, ${ }^{\S}$ Qi He, ${ }^{\star}$ Wen-Sen Lee, ${ }^{\ddagger}$ Saori Kashiki, ${ }^{\star}$ Lauren C. Foster, ${ }^{\star}$ Jer-Chia Tsai, ${ }^{\star}$ Mu-En Lee, ${ }^{\ddagger}$ and Edgar Haber ${ }^{\ddagger}$ \\ *Cardiovascular Biology Laboratory, Harvard School of Public Health; ${ }^{\ddagger}$ Department of Medicine, Harvard Medical School; \\ ${ }^{\S}$ Cardiovascular Division, Beth Israel Hospital; and ${ }^{\| C a r d i o v a s c u l a r ~ D i v i s i o n, ~ B r i g h a m ~ a n d ~ W o m e n ' s ~ H o s p i t a l, ~ B o s t o n, ~ M a s s a c h u s e t t s ~}$ \\ 02115
}

\begin{abstract}
CD44, the principal receptor for hyaluronic acid, is a widely distributed cell surface proteoglycan involved in cellular activation, proliferation, and migration. These processes are also central to the vascular smooth muscle cell's response to arterial wall injury. We evaluated the expression of CD44 and its isoform, CD44-v6, on vascular smooth muscle cells in vitro and in vivo and assessed the role of CD44 in DNA synthesis. Cultured vascular smooth muscle cells expressed CD44 and CD44-v6 at levels equal to or higher than those of the $\boldsymbol{\beta}_{1}$ and $\boldsymbol{\beta}_{3}$ integrins. In a rat carotid artery balloon injury model, CD44 and CD44-v6 mRNAs were upregulated in vascular smooth muscle cells after injury, and CD44 protein expression was greatest at the luminal edge of the growing neointima. CD44-expressing smooth muscle cells proliferated actively, and hyaluronic acid expression increased after injury in a temporal pattern similar to that of CD44. Through binding to hyaluronic acid, CD44 augmented DNA synthesis in cultured human and rat smooth muscle cells by $48 \pm 7.8$ and $100 \pm 12.5 \%$, respectively, an effect inhibited by an anti-CD44 antibody that blocked hyaluronate binding. These observations support a role for CD44 in the reaction of vascular smooth muscle cells to arterial wall injury. (J. Clin. Invest. 1996. 97:596-603.) Key words: proteoglycans $\bullet$ hyaluronic acid $\cdot$ smooth muscle cells $\bullet$ DNA synthesis $\bullet$ carotid artery
\end{abstract}

\section{Introduction}

The migration of smooth muscle cells from their normal place in the tunica media to the intima, their subsequent proliferation, and the formation of a fibrous plaque are central features of the advanced arteriosclerotic lesion. Smooth muscle cell proliferation is also prominent in the occlusive lesions that oc-

M. Jain and Q. He contributed equally to this work.

Address correspondence to Dr. Edgar Haber, Cardiovascular Biology Laboratory, Harvard School of Public Health, 677 Huntington Avenue, Boston, MA 02115. Phone: 617-432-1010; FAX: 617-4324098. E-mail: HABER@CVLAB.HARBARD.EDU. Q. He's present address is Department of Molecular and Cellular Biology, Harvard University, 7 Divinity Avenue, Cambridge, MA 02138. J.-C. Tsai's present address is Kaohsiung Medical College, 100 Shih-Chuan First Road, Kaohsiung, Taiwan.

Received for publication 14 July 1995 and accepted in revised form 14 November 1995.

J. Clin. Invest.

(C) The American Society for Clinical Investigation, Inc.

0021-9738/96/02/0596/08 \$2.00

Volume 97, Number 3, February 1996, 596-603 cur in coronary artery bypass grafts and in the concentric luminal narrowing that follows balloon angioplasty and arteriosclerosis associated with transplantation $(1,2)$. In the course of these processes the smooth muscle cell phenotype changes from that of a contractile cell that replicates slowly to that of a migratory cell that proliferates rapidly and secretes abundant extracellular matrix (3). Soluble growth factors, cytokines, and vasoactive agents released in a paracrine manner by inflammatory cells, or in an autocrine manner by smooth muscle cells themselves, are believed to play important roles in initiating these phenotypic changes. Adhesion and signaling molecules found on the cell surface, such as the $\beta_{1}$ and $\beta_{3}$ integrins $(4,5)$ and vascular cell adhesion molecule-1 (6), have also been implicated in modulating smooth muscle cell function.

CD44 is a cell surface proteoglycan that has been described on a variety of cell types. It is highly pleomorphic: 10 exons encode a CD44 sequence that is expressed generally, but one or more of 10 variable exons can be inserted by alternative splicing $(7,8)$. CD44 plays a role in extracellular matrix binding, cell migration, lymphocyte activation, lymphocyte homing, and proliferation of bronchial smooth muscle cells (7-10). An isoform of CD44 containing the sixth variable exon, CD44-v6, has been shown to confer metastatic potential to rat carcinoma cells (11).

We examine in this study the role of CD44 and its isoform, CD44-v6, in the response of vascular smooth muscle cells to arterial wall injury. We show in vitro that CD44 and CD44-v6 are expressed abundantly on cultured smooth muscle cells. We show in vivo that CD44 and CD44-v6 mRNA and CD44 protein are expressed minimally on smooth muscle cells in the media of normal arteries but are expressed highly on smooth muscle cells in the neointima of injured arteries. We also provide evidence that the specific binding of hyaluronic acid to CD44 on smooth muscle cells produces a significant increase in DNA synthesis.

\section{Methods}

Cell culture. Rat aortic smooth muscle cells (RASMCs) ${ }^{1}$ were harvested from the thoracic aorta of adult male Sprague-Dawley rats (200-250 g) by enzymatic dissociation according to the method of Gunther et al. (12). The cells were grown in DME (JRH Biosciences, Lenexa, KS) supplemented with $10 \%$ FCS, penicillin $(100 \mathrm{U} / \mathrm{ml})$, streptomycin $(100 \mu \mathrm{g} / \mathrm{ml})$, and $25 \mathrm{mM}$ Hepes, $\mathrm{pH} 7.4$, in a humidified incubator $\left(37^{\circ} \mathrm{C}, 5 \% \mathrm{CO}_{2}\right)$. Human aortic smooth muscle cells (HASMCs; Clonetics, San Diego) were grown in M199 medium (GIBCO BRL, Grand Island, NY) containing 20\% FCS, penicillin

1. Abbreviations used in this paper: b-PG, biotinylated proteoglycan; HASMC, human aortic smooth muscle cell; RASMC, rat aortic smooth muscle cell. 
(100 U/ml), streptomycin $(100 \mu \mathrm{g} / \mathrm{ml})$, and $25 \mathrm{mM}$ Hepes (pH 7.4). Cells from passages 5-7 were used.

Amplification of CD44 and CD44-v6 from RASMC. The two cDNA fragments were amplified from RASMC RNA by reverse transcriptase PCR as described (13). Primers were designed according to the published rat CD44 sequence (11). Forward (5' AGCCAGTGACAGGTTCCATT 3') and reverse (5' TGTTGTGTCTTTTCAAGTTA $3^{\prime}$ ) primers were used to amplify a 1,228-bp fragment for CD44, and forward (5' GGCGGATCCTAAATAGCCAACG $3^{\prime}$ ) and reverse (5' GGCGGATCCTTCTGTCACATGGGAG 3') primers were used to amplify a 104-bp fragment representing the v6 exon (CD44-v6). The PCR fragments were then subcloned and their sequences were confirmed by the dideoxy chain termination method (13).

RNA extraction and RNA blot analysis. Tissue from adult male Sprague-Dawley rats that had been subjected to balloon injury of the carotid artery (by the Zivic Miller Company, Zelienople, PA) was studied at various points after injury. Rats were anesthetized with chloral hydrate, and the injured carotid arteries were isolated. Total RNA from carotid arteries was extracted by the RNA-Zol method (Cinna/Biotecx Laboratories International, Houston, TX). Total RNA from RASMCs and HASMCs was obtained by guanidinium isothiocyanate extraction and centrifugation through cesium chloride (13). All RNA was fractionated on a $1.3 \%$ formaldehyde-agarose gel and transferred to nitrocellulose filters, which were hybridized with an appropriate, randomly primed, ${ }^{32} \mathrm{P}$-labeled probe (13). The hybridized filters were washed in $30 \mathrm{mM}$ sodium chloride, $3 \mathrm{mM}$ sodium citrate, and $0.1 \%$ SDS at $55^{\circ} \mathrm{C}$ and autoradiographed on Kodak XAR film at $-80^{\circ} \mathrm{C}$. To correct for differences in RNA loading, we hybridized the blots with an $18 \mathrm{~s}$ oligonucleotide probe. The filters were scanned and radioactivity was measured on a PhosphorImager running the ImageQuant software (Molecular Dynamics, Inc., Sunnyvale, CA).

$\left[{ }^{3} H\right]$ Thymidine incorporation. RASMCs and HASMCs were plated on 24-well plates in growth medium (DME plus 10\% FCS for RASMCs, M199 medium plus 20\% FCS for HASMCs) and incubated for $24 \mathrm{~h}$. They were then made dormant in quiescence medium (DME plus $0.4 \%$ calf serum for RASMCs, M199 medium plus $0.4 \%$ FCS for HASMCs) for 48-72 h (14). Hyaluronic acid (Anika Chemical Company, Boston, MA) was added at various concentrations and the mixture was allowed to incubate for $24 \mathrm{~h}$. In some cases cells were treated before the addition of hyaluronic acid with an anti-human CD44 blocking antibody kindly provided by S.A. Cannistra of the DanaFarber Cancer Institute (Boston, MA) for $1 \mathrm{~h}$ at $4^{\circ} \mathrm{C}(15,16)$. The concentrations of blocking antibody were $1 \mu \mathrm{g} / \mathrm{ml}, 0.1 \mu \mathrm{g} / \mathrm{ml}$, and 0.01 $\mu \mathrm{g} / \mathrm{ml}$ for $1: 100,1: 1,000$, and 1:10,000 dilutions, respectively. A control antifibrinogen antibody $(1 \mu \mathrm{g} / \mathrm{ml} ; \mathrm{IgG} 1)$ was kindly provided by G.L. Reed of the Harvard School of Public Health (Boston, MA). During the last $2 \mathrm{~h}$ of the 24-h incubation with hyaluronic acid, cells were labeled with [methyl- ${ }^{3} \mathrm{H}$ ] thymidine (DuPont-NEN, Boston, $\mathrm{MA})$ at $1 \mu \mathrm{Ci} / \mathrm{ml}(1 \mu \mathrm{Ci}=37 \mathrm{kBq})$. After the cells had been labeled they were washed with Dulbecco's PBS, fixed in cold 10\% TCA, and washed with $95 \%$ ethanol. Incorporated $\left[{ }^{3} \mathrm{H}\right]$ thymidine was extracted in $0.2 \mathrm{~N} \mathrm{NaOH}$ and measured in a liquid scintillation counter. Three samples were analyzed in each experiment, and values were expressed as the mean \pm SEM. Comparisons were subjected to ANOVA, and significance was accepted at $P<0.05$.

Flow cytometry analysis. RASMCs were obtained as described above and briefly exposed to $0.025 \%$ trypsin $/ 1.5 \mathrm{mM}$ EDTA in PBS, washed, and incubated on ice for 30 min with OX-49 antibody (antirat CD44, IgG2a, Pharmingen, San Diego, CA), monoclonal 1.1 ASML antibody (anti-rat CD44-v6, IgG, gift of T. Gerrard, National Institutes of Health, Bethesda, MD), rabbit anti-rat $\beta_{1}$ integrin antiserum (gift of C. Buck, The Wistar Institute, Philadelphia, PA), or F11 antibody (anti-rat $\beta_{3}$ integrin, IgG1, Pharmingen). Labeled cells were washed three times with DME containing $10 \%$ FCS and incubated with FITC-conjugated secondary antibody. Flow cytometry analysis was done on a FACScan ${ }^{\circledR}$.
In situ hybridization. In situ hybridization for CD44 mRNA was performed as described (17) with minor modifications. Adult male Sprague-Dawley rats were perfused with $4 \%$ paraformaldehyde at 2 , 5 , and $8 \mathrm{~d}$ after balloon injury. Carotid arteries were removed, postfixed with $4 \%$ paraformaldehyde, soaked in $30 \%$ sucrose until the tissue had sunk, embedded in optimum cutting temperature compound, and stored in isopentane at $-80^{\circ} \mathrm{C}$ until they were cut at a thickness of $5 \mu \mathrm{m}$. CD44 mRNA was detected by hybridization with a ${ }^{35}$ S $]$ UTP-labeled antisense cRNA probe synthesized with T7 RNA polymerase from XbaI-linearized rat CD44 in Bluescript II SK \pm . For control experiments, a $\left[{ }^{35} \mathrm{~S}\right] \mathrm{UTP}$-labeled sense cRNA probe was synthesized with T3 RNA polymerase from HindIII-linearized rat CD44 in Bluescript II SK \pm . RNA probes were degraded to a length of $\sim$ 500 nucleotides by partial hydrolysis for $5 \mathrm{~min}$ at $60^{\circ} \mathrm{C}$ in $80 \mathrm{mM}$ $\mathrm{NaHCO}_{3}$ and $120 \mathrm{mM} \mathrm{Na} \mathrm{CO}_{3}$. After the hybridization procedure the tissue sections were washed under moderately stringent conditions as described (17). The dried tissue sections were then dipped into Kodak NTB2 emulsion (Eastman Kodak, Rochester, NY) and exposed for $2-4 \mathrm{~d}$ at $4^{\circ} \mathrm{C}$. Counterstaining was performed with hematoxylin-eosin.

Immunocytochemistry. Adult male Sprague-Dawley rats were killed 4, 7, 9, and $16 \mathrm{~d}$ after balloon injury. Carotid arteries were removed, fixed with $4 \%$ paraformaldehyde, and processed for paraffin embedding in an automated system (Hypercenter XP; Shandon Scientific, Pittsburgh, PA). The carotid artery specimens were cut at a thickness of $5 \mu \mathrm{m}$. Immunocytochemical analysis for $\alpha$-actin was performed as described (18) with an mAb against smooth muscle $\alpha$-actin (1:400, anti- $\mathrm{NH}_{2}$-terminal decapeptide, clone 1A4; Sigma Chemical Co., St. Louis, MO). Staining was visualized by an alkaline phosphatase technique. Positive staining was evidenced by the development of a pink/red color.

For the CD44 and proliferating-cell nuclear antigen colocalization study, immunocytochemical double labeling was performed as described $(19,20)$. Paraffin was removed from the sections and they were incubated in PBS containing 10\% normal goat serum and $0.4 \%$ Triton X-100 to reduce nonspecific binding. Monoclonal anti-proliferating-cell nuclear antigen antibody $(3 \mu \mathrm{g} / \mathrm{ml}$, clone PC10, Oncogene Science Inc., Cambridge, MA) was applied for $1 \mathrm{~h}$ at room temperature and then overnight at $4^{\circ} \mathrm{C}$. Sections were washed with PBS and then incubated with biotinylated anti-mouse IgG2a at a dilution of 1:100 for $1 \mathrm{~h}$ at room temperature. They were then washed with PBS and incubated with $3 \% \mathrm{H}_{2} \mathrm{O}_{2}$ for $10 \mathrm{~min}$. After another wash with PBS, the tissue sections were incubated with avidin-biotin complex (ABC elite kit; Vector Laboratories, Burlingame, CA) at a dilution of 1:100 for $1 \mathrm{~h}$ at room temperature. The tissue sections were then washed with PBS and treated with $\mathrm{NiSO}_{4}$ and diaminobenzidine in PBS- $\mathrm{H}_{2} \mathrm{O}_{2}$ for 1-3 min (peroxidase substrate kit DAB; Vector Laboratories) and transferred to PBS solution to stop the reaction.

Tissue sections were incubated in anti-CD $44 \mathrm{mAb}$ OX- 49 for $1 \mathrm{~h}$ at room temperature and then overnight at $4{ }^{\circ} \mathrm{C}$. After a wash with PBS the sections were incubated with biotinylated anti-mouse IgG2a at a dilution of 1:100 for $1 \mathrm{~h}$ at room temperature. They were then washed with PBS and incubated with avidin-biotin complex (ABC elite kit) at a dilution of 1:100 for $1 \mathrm{~h}$ at room temperature. After another wash with PBS the tissue sections were treated with diaminobenzidine in $\mathrm{PBS}-\mathrm{H}_{2} \mathrm{O}_{2}$ for $1-3$ min (peroxidase substrate kit $\mathrm{DAB}$ ) and then transferred to PBS solution to stop the reaction. The presence of proliferating-cell nuclear antigen was demonstrated by the development of a blue/black color in nuclei; CD44 immunoreactivity within the cytoplasm stained brown. Counterstaining was performed with $0.5 \%$ methyl green.

The biotinylated proteoglycan (b-PG) fragments used to detect hyaluronic acid were kindly provided by C. Underhill (Georgetown University, Washington, DC). Immunostaining was performed according to the method of Green et al. (21) with minor modification. Briefly, the paraffin-embedded tissue sections were rehydrated with calcium- and magnesium-free PBS after a deparaffinization procedure and then incubated for $5 \mathrm{~min}$ in $10 \% \mathrm{H}_{2} \mathrm{O}_{2}$ to inactivate endoge- 
quiescent activated

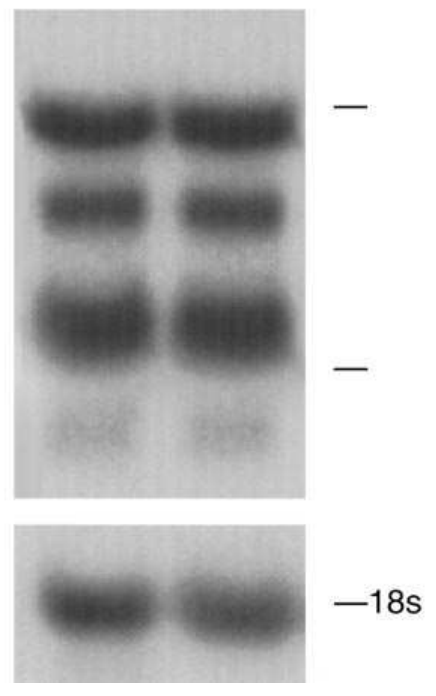

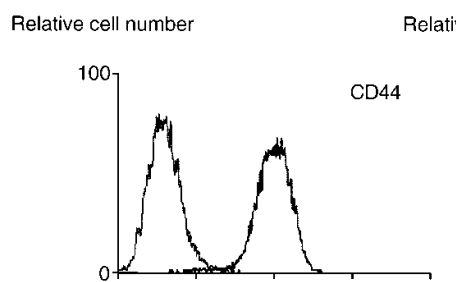

. Expression of $\mathrm{CD}$ mRNA in RASMCs cultured in quiescence medium (DME plus $0.4 \%$ calf serum) and growth medium (DME plus $10 \%$ FCS). Northern analysis was performed with $10 \mu \mathrm{g}$ of total RNA per lane. After electrophoresis, RNA was transferred to nitrocellulose filters and hybridized with a ${ }^{32}$ P-labeled rat CD44 probe. Four transcripts are visible at 1.6, 2.0, 3.3 and $4.5 \mathrm{~kb}$. Filters were hybridized with 18 s to verify equivalent loading.

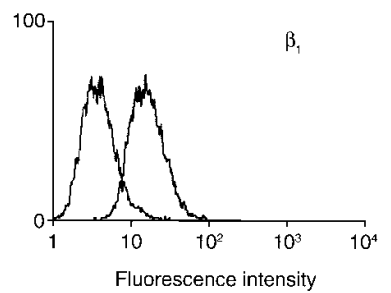

nous peroxidases. Tissue sections were then rinsed in PBS and incubated for $1 \mathrm{~h}$ with $8 \mu \mathrm{g} / \mathrm{ml}$ of b-PG dissolved in $10 \%$ calf serum, $90 \%$ PBS. After a wash with PBS, the tissue sections were incubated with avidin-biotin complex (ABC elite kit) at a dilution of 1:100 for $1 \mathrm{~h}$ at room temperature. Staining was visualized by an immunoperoxidase technique, with diaminobenzidine used as chromogen to yield a brown reaction product. The tissue was counterstained with methyl green for visualization of nuclei. To control for b-PG specificity, we incubated tissue in b-PG that had been absorbed with $0.1 \mathrm{mg} / \mathrm{ml}$ hyaluronic acid; this procedure blocked all staining.

\section{Results}

Expression of $C D 44$ and CD44-v6 $m R N A$ and protein in vitro. Fig. 1 shows that CD44 mRNA was expressed abundantly in RASMCs incubated in growth medium (DME plus $10 \% \mathrm{FCS}$ ) and in quiescence medium (DME plus $0.4 \%$ calf serum). A heterogeneous mixture of mRNAs $(1.6 \mathrm{~kb}, 2.0 \mathrm{~kb}$, $3.3 \mathrm{~kb}$, and $4.5 \mathrm{~kb}$ ) was apparent in resting as well as activated smooth muscle cells, at sizes similar to those reported elsewhere for CD44 (11). These various CD44 isoforms could have been caused by alternative splicing or by multiple polyadenylation sites (22).

We performed flow cytometry analysis to determine whether CD44 and CD44-v6 were present on the surface of vascular smooth muscle cells and to allow comparison of their expression with that of other cell surface proteins. CD44 surface antigen was highly expressed on RASMCs (Fig. 2, top left), and a comparison of this expression pattern with those for the $\beta_{1}$ and $\beta_{3}$ integrins (Fig. 2, bottom left and right) revealed that the amount of CD44 was in excess of those of the two integrin chains. CD44-v6 surface antigen was also detected at levels equal to or slightly higher than either integrin chain (Fig. 2, top right). Thus, CD44 and its v6 isoform appear to be expressed abundantly on vascular smooth muscle cells in culture.

CD44 and CD44-v6 mRNA expression in vivo. To better evaluate CD44 and CD44-v6 in differentiated and dedifferentiated smooth muscle cells, we examined their expression in vivo in rat carotid arteries before and after $(2,5$, and $8 \mathrm{~d})$ balloon injury $(23,24)$. (These time points were chosen to reflect
Relative cell number
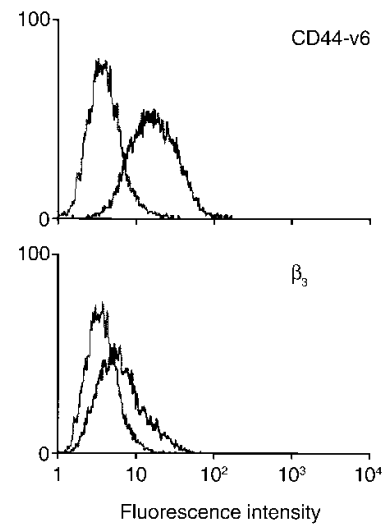

Figure 2. Expression of CD44, CD44-v6, integrin $\beta_{1}$, and integrin $\beta_{3}$ on the surface of cultured RASMCs. Flow cytometry analysis was performed on cultured RASMCs grown to $80 \%$ confluence, detached with trypsin, and resuspended in fresh medium (DME plus 10\% FCS). Application of a specific antibody to surface antigen was followed by application of a second antibody conjugated to FITC.

periods in which smooth muscle cells are maximally activated after injury.) CD44 mRNA expression in the normal, uninjured rat carotid artery was minimal (Fig. 3, left). However, $2 \mathrm{~d}$ after carotid artery injury, a time when smooth muscle cells in the media replicate actively (24), a 3.6-fold increase in CD44 mRNA was visible. mRNA levels decreased 5 and $8 \mathrm{~d}$ after injury but remained above base line. CD44-v6 expression (Fig. 3, right) was upregulated even more dramatically after injury. A 7.5-fold increase in CD44-v6 mRNA was seen after $2 \mathrm{~d}$. mRNA levels decreased to $\sim$ fivefold above base line at later time points.

At the same time points at which the Northern blot analyses of CD44 were performed we examined carotid artery sections by in situ hybridization to confirm that CD44 expression was localized to vascular smooth muscle cells in the injured artery. For each antisense experiment with a CD44 riboprobe (Fig. 4, left), a corresponding sense (control) experiment (Fig. 4 , right) was performed. Fig. $4 a$ shows that there was little expression of CD44 in the normal tunica media. At $2 \mathrm{~d}$ after in-

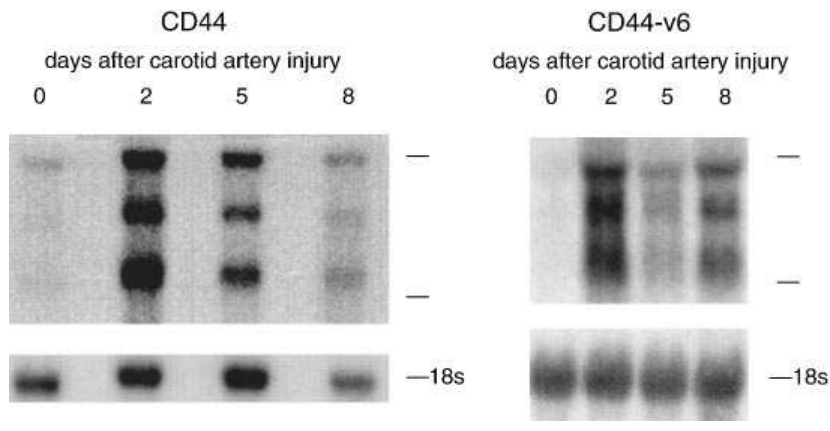

Figure 3. Expression of CD44 and CD44-v6 mRNA 2, 5, and $8 \mathrm{~d}$ after balloon injury in rat carotid arteries. Northern analysis was performed with $10 \mu \mathrm{g}$ of total RNA per lane for CD44 and $20 \mu \mathrm{g}$ of total RNA per lane for CD44-v6. After electrophoresis, RNA was transferred to nitrocellulose filters and hybridized with the appropriate ${ }^{32} \mathrm{P}$-labeled probe. Three transcripts are visible for CD44 and CD44-v6. Filters were hybridized with 18 s to verify equivalent loading. 

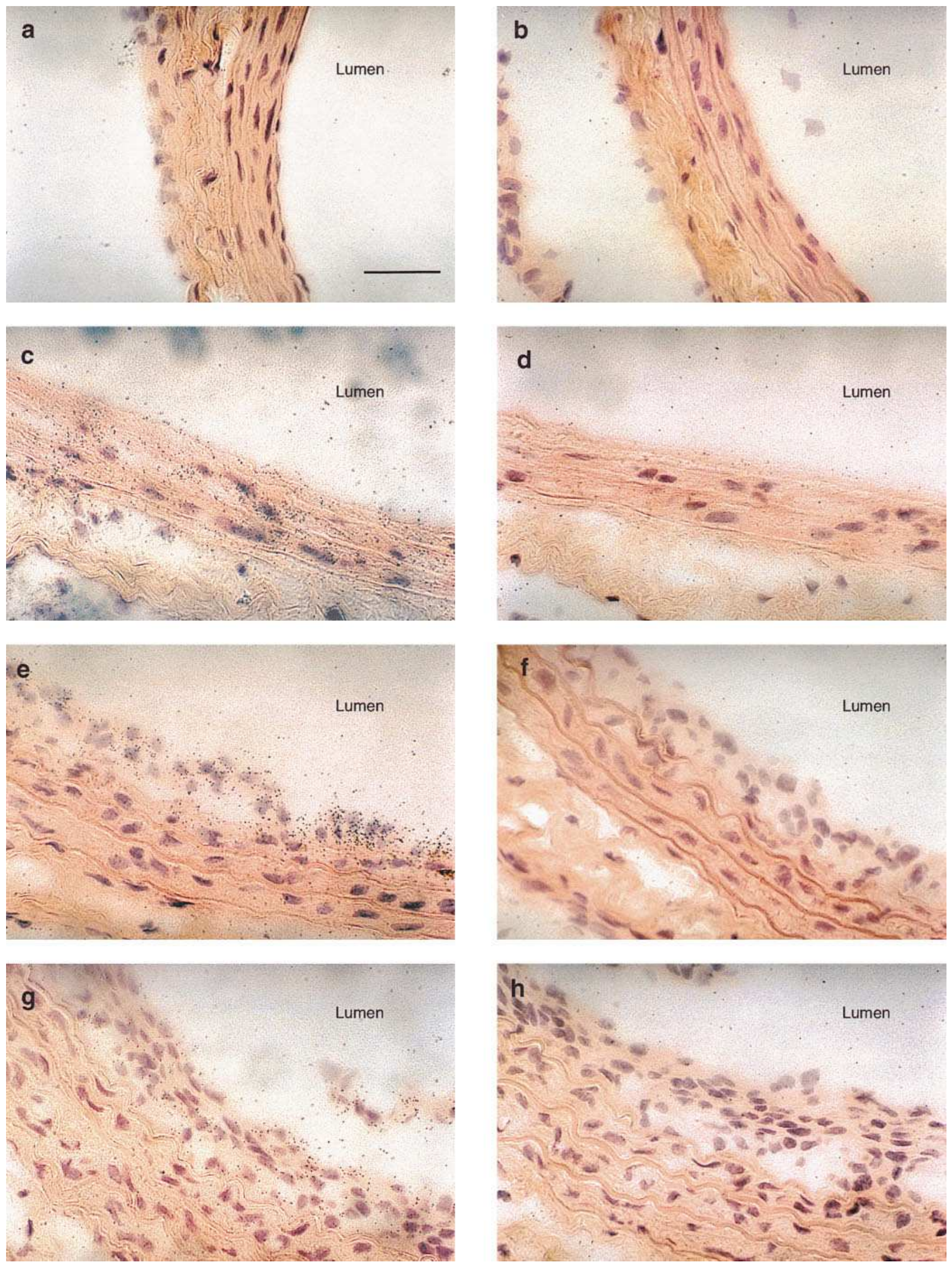

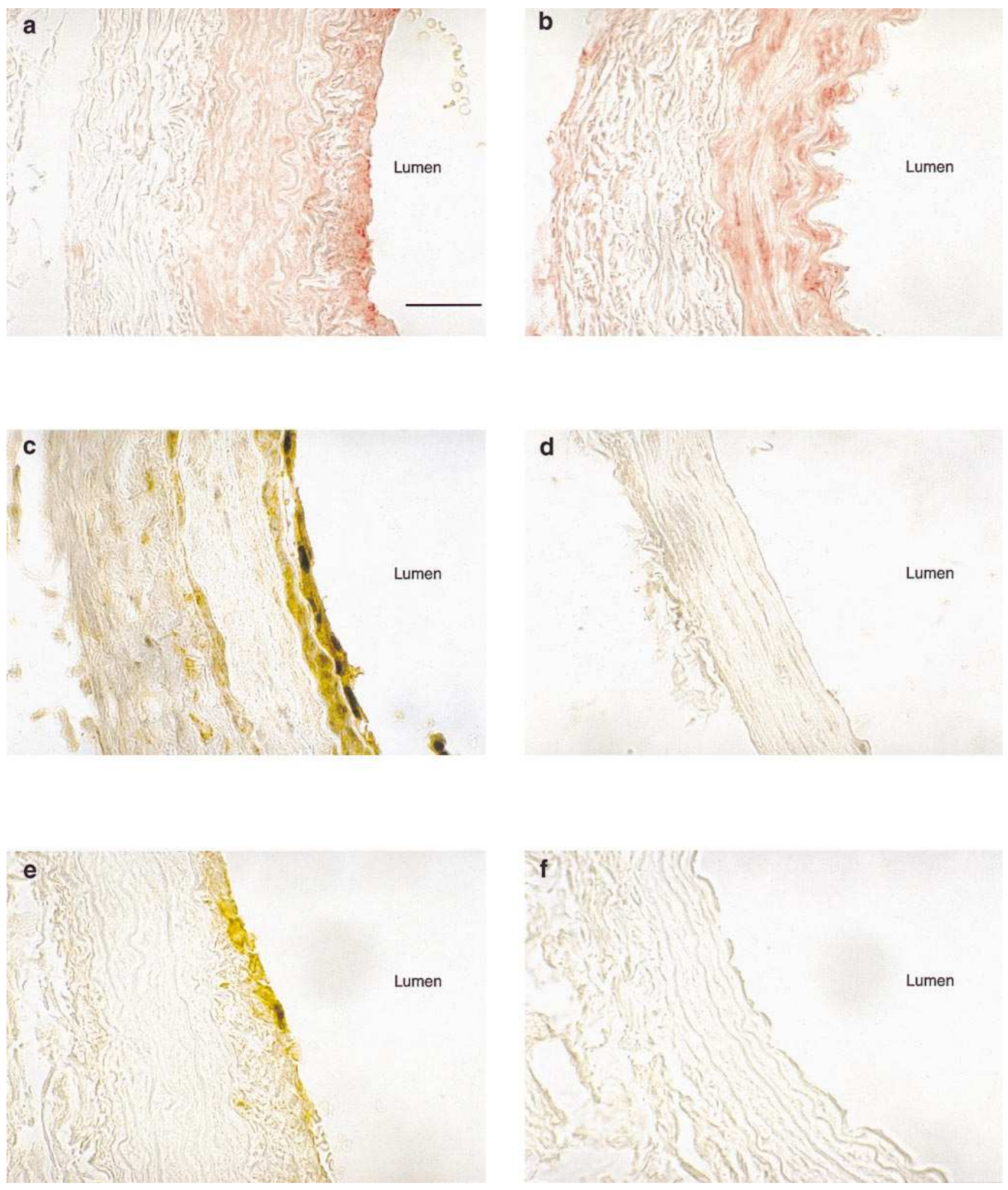

Figure 5. Immunocytochemical analysis of CD44 expression after balloon injury in rat carotid arteries. Uninjured contralateral (right) and injured (left) carotid arteries stained for $\alpha$-actin (pink) $7 \mathrm{~d}$ after injury $(a)$ and double stained for CD44 (yellow brown) and proliferating-cell nuclear antigen (black) $4(c)$ and $7(e) \mathrm{d}$ after injury. Scale bar in $a, 1.5 \mathrm{~cm}=25 \mu \mathrm{m}$. Original magnification $\times 600$.

Figure 4. In situ analysis of CD44 expression after balloon injury in rat carotid arteries. CD44 mRNA was assayed with $\left[{ }^{35}\right.$ S]UTP-labeled antisense (left) and sense (right) cRNA probes in uninjured arteries $(a$ and $b)$ and arteries $2 \mathrm{~d}(c$ and $d), 5 \mathrm{~d}(e$ and $f)$, and $8 \mathrm{~d}(g$ and $h)$ after injury. Scale bar in $a, 1.5 \mathrm{~cm}=25 \mu \mathrm{m}$. Original magnification $\times 600$. 

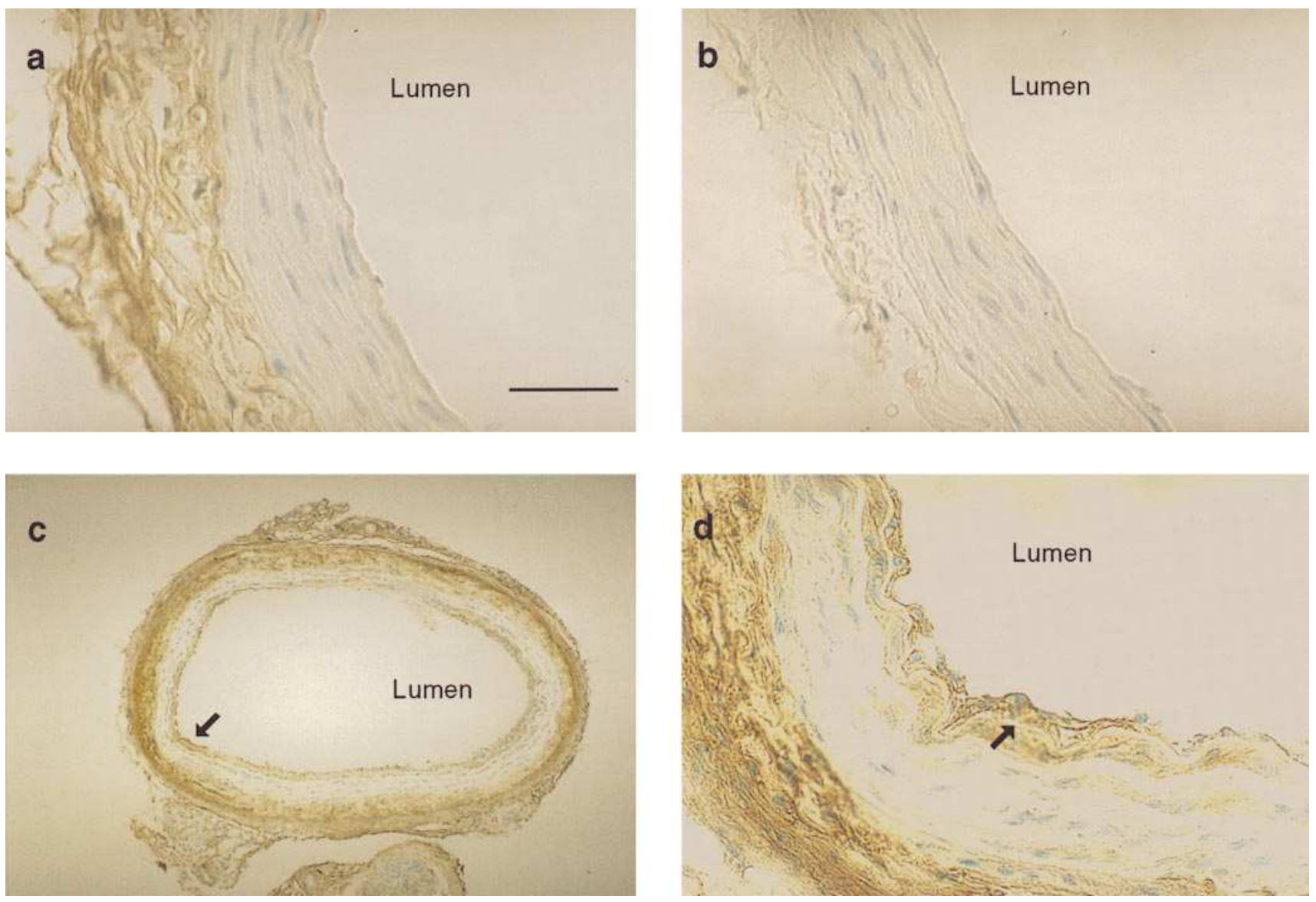

Figure 6. Immunocytochemical analysis of hyaluronic acid expression after balloon injury in rat carotid arteries. Uninjured carotid artery (a) and injured carotid arteries stained for hyaluronic acid (brown) $4 \mathrm{~d}$ after injury ( $c$ and $d$ ). Absence of staining after preabsorption with hyaluronic acid in an uninjured carotid artery $(b)$ demonstrates specificity. Arrows in $c$ and $d$ point to hyaluronic acid staining in the neointima. Scale bar in $a, 1.5 \mathrm{~cm}=25 \mu \mathrm{m}$ in $a, b$, and $d ; 1.5 \mathrm{~cm}=75 \mu \mathrm{m}$ in $c$. Original magnification $\times 600$ in $a, b$, and $d$; Original magnification $\times 200$ in $c$.

jury (Fig. 4 c) CD44 expression (silver grains, black) increased markedly in the smooth muscle cells composing the tunica media. Formation of neointima was apparent at $5 \mathrm{~d}$ after injury (Fig. $4 e$ ), and the greatest concentration of silver grains was in the neointima. By $8 \mathrm{~d}$ after injury (Fig. $4 \mathrm{~g}$ ) CD44 expression diminished in the neointima. These in situ data correlate with those from the Northern analysis (Fig. 3) and indicate that the smooth muscle cells activated as a result of injury, both in the tunica media and in the neointima, expressed high levels of CD44 mRNA.

CD44 protein expression in vivo. We performed immunocytochemical analysis to determine whether $\mathrm{CD} 44$ protein was upregulated in injured (Fig. 5, left) versus uninjured (Fig. 5, right) arterial walls. Tissue sections were first stained with anti- $\alpha$-actin antibody (Fig. $5 a$ and $b$ ) to confirm the presence of smooth muscle cells in the neointima $7 \mathrm{~d}$ after injury. In tissue sections double stained for CD44 and proliferating-cell nuclear antigen (Fig. $5 c-f$ ), intense colocalized staining was visible $4 \mathrm{~d}$ after injury in the neointimal region closest to the lumen of the vessel (Fig. $5 c$ ). No staining was visible in the uninjured contralateral carotid artery from the same animal (Fig. $5 d$ ). At $7 \mathrm{~d}$ after injury a well-developed neointima was visible, with CD44 staining mainly in the neointima (Fig. 5, $e$ versus $f$ ). Together with the in situ hybridization data, these im- munocytochemical data indicate that CD44 is expressed highly in vascular smooth muscle cells activated after injury.

Hyaluronic acid expression in vivo. In the reaction to arterial injury, vascular smooth muscle cells proliferate and secrete extracellular matrix $(2,3)$. Hyaluronic acid, one of the wellstudied ligands for $\mathrm{CD} 44$, is a common extracellular matrix product. We performed immunocytochemical analysis to determine whether the increase in CD44 expression after injury was accompanied by an increase in hyaluronic acid production. Using a b-PG probe specific for hyaluronic acid (21), we evaluated hyaluronic acid expression in injured and uninjured arterial walls. Fig. $6 a$ shows the pattern for hyaluronic acid staining in an uninjured carotid artery. Brown staining representing hyaluronic acid was visible only in the adventitia; no appreciable staining was apparent in the tunica media. We confirmed b-PG specificity by preabsorbing it with hyaluronic acid (see Methods), which blocked all staining (Fig. $6 b$ ). However, at $4 \mathrm{~d}$ after balloon injury, hyaluronic acid staining was visible throughout the neointima (Fig. $6 c$ and $d$, arrows). The intensity of staining decreased by $9 \mathrm{~d}$ after injury and was barely detectable by $16 \mathrm{~d}$ (not shown). This temporal pattern and location of hyaluronic acid expression was similar to that of CD44 after arterial injury (Fig. $5 c-f$ ).

Binding of hyaluronic acid to CD44 increases DNA synthe- 

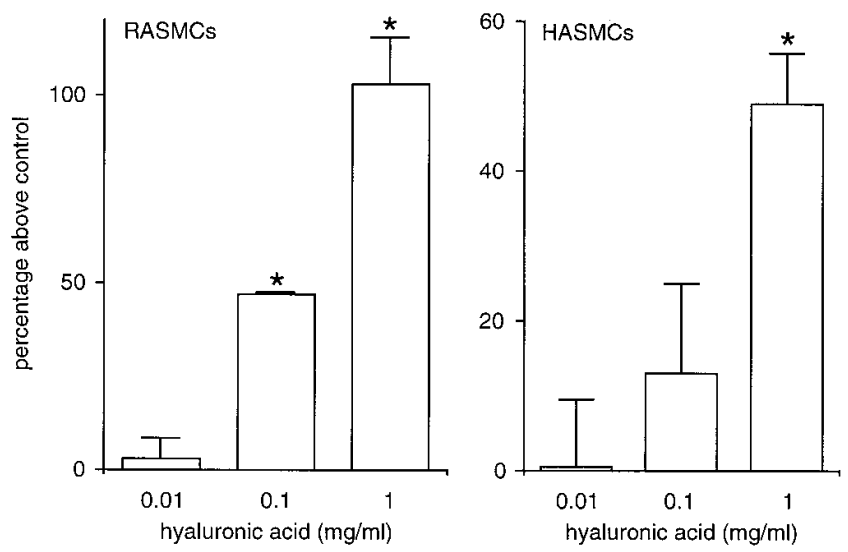

Figure 7. Effect of hyaluronic acid on $\left[{ }^{3} \mathrm{H}\right]$ thymidine incorporation in smooth muscle cells. RASMCs and HASMCs were made quiescent for 48-72 $\mathrm{h}$ and incubated with the indicated concentrations of hyaluronic acid. Thymidine incorporation is expressed as a percent increase above the value for untreated quiescent cells (standardized to zero; raw value of 4,175 \pm 286 for RASMCs and $272 \pm 20$ for HASMCs). Values represent the mean \pm SEM from three wells. $* P<0.05$ vs. control. Results from a representative experiment are shown $(n=3)$

sis in vascular smooth muscle cells. Since CD44 has been postulated to act as both an adhesion molecule and a signaling molecule, we examined whether binding of hyaluronic acid to CD44 increased $\left[{ }^{3} \mathrm{H}\right]$ thymidine incorporation, a measure of DNA synthesis, in rat and human aortic smooth muscle cells. Addition of increasing concentrations of hyaluronic acid produced a dose-dependent increase in thymidine incorporation in RASMCs and HASMCs (Fig. 7). At hyaluronic acid concentrations of $>1 \mathrm{mg} / \mathrm{ml}$, thymidine incorporation did not increase further (data not shown). Because the addition of chondroitin sulfate $(0.01-1 \mathrm{mg} / \mathrm{ml})$ did not significantly augment thymidine incorporation (data not shown), this effect of hyaluronic acid appears to have been specific.

To confirm that binding of hyaluronic acid to CD44 was responsible for the observed increase in thymidine incorporation in the presence of hyaluronate, we repeated these measurements in the presence of an antibody that blocks the binding of hyaluronic acid to human CD44 (16). (We studied HASMCs only because a blocking antibody for rat CD44 was not available.) Although the blocking antibody alone had no effect on thymidine incorporation (Fig. 8), treatment with the blocking antibody before addition of hyaluronic acid prevented augmentation of thymidine incorporation. In contrast, treatment with a control antibody failed to prevent an increase in thymidine incorporation. These data suggest that the increase in thymidine incorporation in smooth muscle cells treated with hyaluronic acid was mediated through CD44.

\section{Discussion}

To our knowledge this study is first to establish that CD44 and CD44-v6 (which are minimally expressed on normal, differentiated vascular smooth muscle cells in vivo) are greatly upregulated after arterial wall injury. In cultured smooth muscle cells, CD44 and its v6 isoform are highly expressed cell surface proteins, present at levels equal to or in excess of those of the $\beta_{1}$ and $\beta_{3}$ integrins. The specific binding to CD44 of hyaluronic

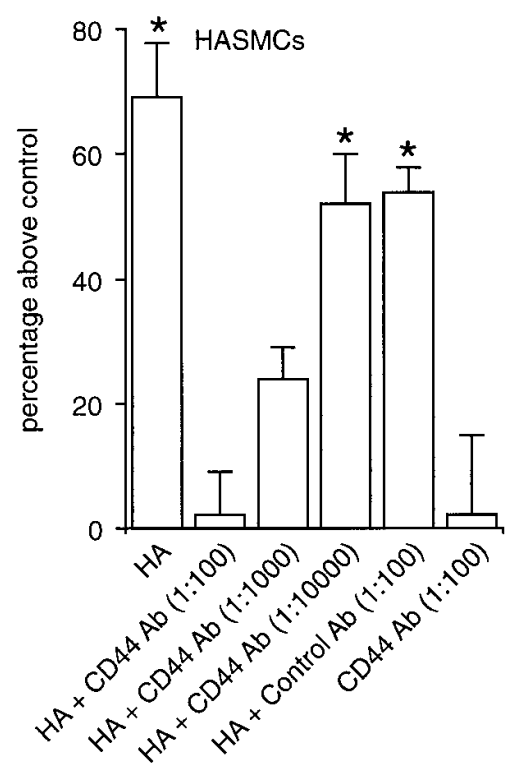

Figure 8. Effect of CD44 blocking antibody on $\left[{ }^{3} \mathrm{H}\right]$ thymidine incorporation in HASMCs. HASMCs were made quiescent for 48-72 $\mathrm{h}$ and incubated with the indicated concentrations of antibody for $1 \mathrm{~h}$ before addition of hyaluronic acid $(H A, 1 \mathrm{mg} / \mathrm{ml})$. Thymidine incorporation is expressed as a percent increase above the value for untreated quiescent cells (standardized to zero; raw value of 1,404 \pm 193 ). Values represent the mean \pm SEM from three wells. $* P<0.05$ vs. control. Results from a representative experiment are shown $(n=3)$.

acid, an extracellular matrix constituent, increases DNA synthesis in vascular smooth muscle cells in culture.

The response of vascular smooth muscle cells to arterial injury has been the focus of considerable interest. Much effort has been dedicated to the roles of cytokines, growth factors, and vasoactive agents. In addition, components of the extracellular matrix have been shown to affect phenotype and function in vascular smooth muscle cells $(3,25)$. Components of the extracellular matrix are bound by two principal families of cell surface molecules, the integrins and the proteoglycans. The integrins are associated with both intracellular signaling and regulation of cellular motility (26). For example, Guan et al. (27) showed that the interaction between fibronectin and a $\beta_{1}$ integrin induces phosphorylation on an intracellular $120-\mathrm{kD}$ protein. Skinner et al. (5) showed that $\alpha_{2} \beta_{1}$ integrins are required for vascular smooth muscle cell chemotaxis across type 1 collagen membranes, and Liaw et al. (28) showed that $\alpha_{v} \beta_{3}$ integrins are essential for the migration of vascular smooth muscle cells in response to the acidic glycoprotein osteopontin.

The principal receptors for hyaluronic acid are the protein RHAMM and the proteoglycan CD44. Savani et al. (29) showed that RHAMM is necessary for the migration of bovine aortic smooth muscle cells after wounding injury. We demonstrate here that expression of CD44 and its v6 isoform increases greatly after arterial wall injury. We also show that levels of hyaluronic acid, the principal ligand for CD44, increase after injury in a temporal pattern similar to that of CD44. Smooth muscle cells are principally responsible for the synthesis of extracellular matrix products after injury $(2,3)$. By upregulating both the receptor (CD44) and its ligand (hyaluronic acid), smooth muscle cells may establish an autocrine form of stimulation. As our experiments summarized in Figs. 7 and 8 show, this form of stimulation does lead to an increase in DNA synthesis. Elimination of this response with a blocking antibody confirmed that the increase in DNA synthesis is mediated through the binding of hyaluronate to CD44. 
We also show that the CD44-v6 variant is expressed on cultured smooth muscle cells and that its message is highly upregulated after vessel injury. The CD44 isoform containing the sixth variable exon has been shown to confer metastatic potential to rat carcinoma cells (11). The intriguing possibility that this isoform plays an analogous role affecting smooth muscle migration after vessel injury will be the focus of future work. Our present data in support of a role for CD44 and its isoform, CD44-v6, in the smooth muscle cell's response to injury should have implications for the pathogenesis of the many manifestations of vascular disease that involve smooth muscle cell activation and proliferation.

\section{Acknowledgments}

We thank Bonna Ith for technical assistance and Thomas McVarish and Photina Ree for editorial assistance.

This work was supported by a grant from the Bristol-Myers Squibb Pharmaceutical Research Institute. Dr. Lee was supported by a Clinician Scientist Award and a Grant-in-Aid from the American Heart Association (AHA), with funds contributed in part by the AHA, Massachusetts Affiliate.

\section{References}

1. Billingham, M.E. 1989. Graft coronary disease: the lesions and the patients. Transplant. Proc. 21:3665-3666.

2. Ross, R. 1993. The pathogenesis of atherosclerosis: a perspective for the 1990s. Nature (Lond.). 362:801-809.

3. Raines, E.W., and R. Ross. 1993. Smooth muscle cells and the pathogenesis of the lesions of atherosclerosis. Br. Heart J. 69:S30-S37.

4. Clyman, R.I., F. Mauray, and R.H. Kramer. 1992. $\beta_{1}$ and $\beta_{3}$ integrins have different roles in the adhesion and migration of vascular smooth muscle cells on extracellular matrix. Exp. Cell Res. 200:272-284.

5. Skinner, M.P., E.W. Raines, and R. Ross. 1994. Dynamic expression of $\alpha_{1} \beta_{1}$ and $\alpha_{2} \beta_{1}$ integrin receptors by human vascular smooth muscle cells. $\alpha_{2} \beta_{1}$ Integrin is required for chemotaxis across type I collagen-coated membranes. Am. J. Pathol. 145:1070-1081.

6. O'Brien, K.D., M.D. Allen, T.O. McDonald, A. Chait, J.M. Harlan, D. Fishbein, J. McCarthy, M. Ferguson, K. Hudkins, C.D. Benjamin, R. Lobb, and C.E. Alpers. 1993. Vascular cell adhesion molecule-1 is expressed in human coronary atherosclerotic plaques. Implications for the mode of progression of advanced coronary atherosclerosis. J. Clin. Invest. 92:945-951.

7. Lesley, J., R. Hyman, and P.W. Kincade. 1993. CD44 and its interaction with extracellular matrix. Adv. Immunol. 54:271-335.

8. Günthert, U. 1993. CD44: a multitude of isoforms with diverse functions. In Adhesion in Leukocyte Homing and Differentiation. D. Dunon, C.R. Mackay, and B.A. Imhof, editors. Springer-Verlag, New York. 47-63.

9. Herrlich, P., M. Zoller, S.T. Pals, and H. Ponta. 1993. CD44 splice variants: metastases meet lymphocytes. Immunol. Today. 14:395-399.
10. Lazaar, A.L., S.M. Albelda, J.M. Pilewski, B. Brennan, E. Puré, and R.A. Panettieri, Jr. 1994. T lymphocytes adhere to airway smooth muscle cells via integrins and CD44 and induce smooth muscle cell DNA synthesis. J. Exp. Med. 180:807-816.

11. Günthert, U., M. Hofmann, W. Rudy, S. Reber, M. Zöller, I. Haußmann, S. Matzku, A. Wenzel, H. Ponta, and P. Herrlich. 1991. A new variant of glycoprotein CD44 confers metastatic potential to rat carcinoma cells. Cell. 65 : $13-24$.

12. Gunther, S., R.W. Alexander, W.J. Atkinson, and M.A. Gimbrone, Jr. 1982. Functional angiotensin II receptors in cultured vascular smooth muscle cells. J. Cell Biol. 92:289-298.

13. Sambrook, J., E.F. Fritsch, and T. Maniatis. 1989. Molecular Cloning, 2nd ed. Cold Spring Harbor Laboratory Press, Cold Spring Harbor, NY. 7.19-13.7.

14. Rao, G.N., M.A. Corson, and B.C. Berk. 1991. Uric acid stimulates vascular smooth muscle cell proliferation by increasing platelet-derived growth factor A-chain expression. J. Biol. Chem. 266:8604-8608.

15. Kansas, G.S., G.S. Wood, and M.O. Dailey. 1989. A family of cell-surface glycoproteins defined by a putative anti-endothelial cell receptor antibody in man. J. Immunol. 142:3050-3057.

16. Cannistra, S.A., G.S. Kansas, J. Niloff, B. DeFranzo, Y. Kim, and C. Ottensmeier. 1993. Binding of ovarian cancer cells to peritoneal mesothelium in vitro is partly mediated by CD44H. Cancer Res. 53:3830-3838.

17. Lee, W.-S., M.J. Berry, M.A. Hediger, and P.R. Larsen. 1993. The type I iodothyronine $5^{\prime}$-deiodinase messenger ribonucleic acid is localized to the S3 segment of the rat kidney proximal tubule. Endocrinology. 132:2136-2140.

18. Shi, C., M.E. Russell, C. Bianchi, J.B. Newell, and E. Haber. 1994. Murine model of accelerated transplant arteriosclerosis. Circ. Res. 75:199-207.

19. Lee, W.-S., M.S. Smith, and G.E. Hoffman. 1990. Luteinizing hormonereleasing hormone neurons express Fos protein during the proestrous surge of luteinizing hormone. Proc. Natl. Acad. Sci. USA. 87:5163-5167.

20. Yoshizumi, M., W.-S. Lee, C.-M. Hsieh, J.-T. Tsai, J. Li, M.A. Perrella, C. Patterson, W.O. Endege, R. Schlegel, and M.-E. Lee. 1995. Disappearance of cyclin A correlates with permanent withdrawal of cardiomyocytes from the cell cycle in human and rat hearts. J. Clin. Invest. 95:2275-2280.

21. Green, S.J., G. Tarone, and C.B. Underhill. 1988. Distribution of hyaluronate and hyaluronate receptors in the adult lung. J. Cell Science. 89:145-156.

22. Shtivelman, E., and J.M. Bishop. 1991. Expression of CD44 is repressed in neuroblastoma cells. Mol. Cell. Biol. 11:5446-5453.

23. Clowes, A.W., M.A. Reidy, and M.M. Clowes. 1983. Mechanisms of stenosis after arterial injury. Lab. Invest. 49:208-215.

24. Clowes, A.W., M.A. Reidy, and M.M. Clowes. 1983. Kinetics of cellular proliferation after arterial injury. I. Smooth muscle growth in the absence of endothelium. Lab. Invest. 49:327-333.

25. Carey, D.J. 1991. Control of growth and differentiation of vascular cells by extracellular matrix proteins. Annu. Rev. Physiol. 53:161-177.

26. Hynes, R.O. 1992. Integrins: versatility, modulation, and signaling in cell adhesion. Cell. 69:11-25.

27. Guan, J.L., J.E. Trevithick, and R.O. Hynes. 1991. Fibronectin/integrin interaction induces tyrosine phosphorylation of a 120-kDa protein. Cell Regul. 2:951-964.

28. Liaw, L., M.P. Skinner, E.W. Raines, R. Ross, D.A. Cheresh, S.M Schwartz, and C.M. Giachelli. 1995. The adhesive and migratory effects of osteopontin are mediated via distinct cell surface integrins. Role of $\alpha_{v} \beta_{3}$ in smooth muscle cell migration to osteopontin in vitro. J. Clin. Invest. 95:713-724.

29. Savani, R.C., C. Wang, B. Yang, S. Zhang, M.G. Kinsella, T.N. Wight, R. Stern, D.M. Nance, and E.A. Turley. 1995. Migration of bovine aortic smooth muscle cells after wounding injury. The role of hyaluronan and RHAMM. J. Clin. Invest. 95:1158-1168. 